Abstracta Iranica Abstracta Iranica

Revue bibliographique pour le domaine irano-aryen

Volume 25 | 2004

Comptes rendus des publications de 2002

\title{
" The Imâm Ja'far al-Sâdiq, Abû al-Khattâb and the Abbasids ». Der Islam, 79/1, (2002), pp. 118-140.
}

\section{Antoine Borrut}

\section{(2) OpenEdition}

1 Journals

\section{Édition électronique}

URL : http://journals.openedition.org/abstractairanica/4838

DOI : $10.4000 /$ abstractairanica.4838

ISSN : 1961-960X

Éditeur :

CNRS (UMR 7528 Mondes iraniens et indiens), Éditions de l'IFRI

\section{Édition imprimée}

Date de publication : 15 mai 2004

ISSN : 0240-8910

\section{Référence électronique}

Antoine Borrut, « " The Imâm Ja'far al-Sâdiq, Abû al-Khattâb and the Abbasids ». Der Islam, 79/1,

(2002), pp. 118-140. », Abstracta Iranica [En ligne], Volume 25|2004, document 239, mis en ligne le 15 mars 2006, consulté le 25 septembre 2020. URL : http://journals.openedition.org/abstractairanica/ 4838 ; DOI : https://doi.org/10.4000/abstractairanica.4838

Ce document a été généré automatiquement le 25 septembre 2020.

Tous droits réservés 


\title{
" The Imâm Ja'far al-Sâdiq, Abû al- Khattâb and the Abbasids ». Der Islam, 79/1, (2002), pp. 118-140.
}

\author{
Antoine Borrut
}

1 Claude Cahen avait été l'un des premiers à mettre en lumière les relations qui unissaient les « révolutionnaires » Abbassides et les chiites, notamment dans le cadre du développement de la da $w a$. On le sait, ces derniers ne furent pas associés au pouvoir par la nouvelle dynastie, ce qui ne manqua pas de provoquer des heurts. En centrant son étude autour de l'un des protagonistes majeurs de la période, le sixième imam Ja'far al-Sâdiq, l'A. apporte ici de précieuses informations relatives aux relations conflictuelles qui en découlèrent. Face à la jeune dynastie, al-Sâdiq fut suspecté, a priori à tort, d'ambitions califales visant à renverser les Abbassides. Au sein même des chiites, des épisodes délicats se nouèrent avec Abû al-Khattâb et les Khattâbiyya (groupe de ghulât). La question des velléités d'usurpation par ce dernier du rôle prédominant d'al-Sâdiq parmi les chiites de Kûfa en témoigne. Quoi qu'il en soit, l'un comme l'autre représentaient une menace pour les Abbassides, ce qui motivera l'assassinat d'Abû alKhattâb par les Abbassides sur les bords de l'Euphrate, alors qu'il fomentait peut-être une rébellion. Cette étude permet de préciser certaines des dissensions qui secouèrent les différents acteurs de la « Révolution Abbasside » au lendemain du renversement des Omeyyades, et les nouveaux mécontentements qui surgirent alors.

\section{INDEX}

Thèmes : 7. Islam 
AUTEURS

ANTOINE BORRUT

IFAPO - Damas 